\title{
Optimization of Learning Media to Improve Lecture Outcomes in Phonology Courses
}

\author{
Sonezza Ladyanna ${ }^{1}$, Aslinda ${ }^{2}$ \\ \{sonezzaladyanna@hum.unand.ac.id, aslindaa64@gmail.com\} \\ ${ }^{1,2}$ Fakultas Ilmu Budaya, Universitas Andalas, Padang, Indonesia
}

\begin{abstract}
Optimization of instructional media is expected to increase student understanding of lecture material so as to improve lecture results. Therefore, research was conducted on the use of video media as a report on group discussions in phonology courses. So, this article aims to explain the use of video media in optimizing learning media to improve the results of phonology lectures. This research was conducted using qualitative methods. Data was collected by conducting classroom action research on phonology class students who are second semester students in the Indonesian Literature Study Program. After that, the data are analyzed by comparing the results of lectures with the media tested with the results of previous lectures. Thus, the results are obtained that lectures by optimizing learning media especially the use of video as a report of group discussions on weekly learning material can increase student understanding as evidenced by increasing student final grades.
\end{abstract}

Keywords: Learning Optimization, Learning Media, Phonology, Educational Facilities and Infrastructure.

\section{Introduction}

Optimization of instructional media is expected to increase student understanding of lecture material so as to improve lecture results. Among these are video media both made by students and those already available in the network. Moreover, if the learning process is carried out using an inquiry approach, which the teacher not only gives knowledge to students but also builds knowledge in his mind independently [1]. This is one of the concepts in learning phonology.

Phonology course is a compulsory subject in the field of linguistics, Indonesian Literature Study Program. This subject is a basic requirement for conditional courses in the following semester. So, this course is given to students of the second semester, to take compulsory courses in semesters three to 6 , students must pass this course. For students, this course is something new because it was never taught in high school.

In phonology, phonetics and phonemics are explained, namely how language sounds are spoken by humans, variations in language sounds, and in the end students will learn to find the sounds of language in a language and determine the phonemes of that language. So, students must master the human speech tool, the process of pronunciation, basic sound waves, and language symbols. By knowing the sound system, students are ready to implement it in advanced linguistic studies including interdisciplinary. For example, graduates or alumni can solve the problem of language disorders that occur in humans, both those brought from birth or due to neurological disorders such as strokes, and trauma caused by collisions and others. In fact, students can explain unusual sounds in a foreign language by referring directly to the utterance so that the difficulty of learning sounds in a foreign language has a solution. 
During this time, it has been taught to students a variety of material related to phonology studies. Starting from the understanding of terms, the names of utterances, the process of the occurrence of language sounds in humans, international standard sound symbols commonly used by international experts, namely the IPA (International Phonetics Association) system, to how to obtain sound data of a language. Then, students will conduct field practice in an area to practice and get directly the sound data of a language. After that, students will learn phonemic analysis so they can find the phoneme system of a language.

The method applied is guided by the SCL system with a central teaching process for students. Students discuss in small groups before coming to class about material for the week. Then, it present in class. Other class members will respond to the presentation. After that, the lecturer will explain the parts that are wrong and emphasize the parts that are less understood by students. After the midterm exams, field lecture practices are conducted. Students will make a research report accompanied by a lecturer.

The assessment is carried out with several types of evaluations. First, how were the results of small group discussions, how the process of presentation and class discussion, the results of the quiz, and how the role of students in the practice of field lectures. The process of making reports and report results is also included in the assessment, in addition to the midterm and final semester assessments have a significant influence on the student's final grade.

The distribution of the student's final grades shows an uneven distribution for each grade category. In general, students only get the highest B + scores. Values of A- and A are not very many or can be said to be very few. In fact, many students get the final result on the value of B- to E. Meanwhile, with the process that has been done, it can be expected that students will get a dominant value of $\mathrm{B}+$ to $\mathrm{A}$.

Considering this lecture is given to first-year students, namely the second semester, this should be further considered. Assessment is one important way to evaluate the learning process during the semester, including how students, how the material, methods, and learning technology are used. Another problem in this lecture is the lack of student behavior during class discussions. Only a few students pay attention and respond to presentations so they will only understand well the material they are presenting. Occasionally, class discussion seems lackluster and there is a vacuum.

Based on the above phenomena, the research is conducted. The use of video as the media to report the result fo group discussion is used in Phonology Class. The article is aimed at explaining the use of video as the media to learn and to optimize the achievement of the students.

\section{Research Method}

This research was conducted with quantitative and qualitative methods. Data was collected by conducting classroom action research on phonology class students who are second semester students in the Indonesian Literature Study Program, Faculty of Cultural Sciences, Andalas University. The number of students in this class is 43 people with an average age of 19 years, which is the 4.0 generation close to the use of social media.

Bearing in mind that learning methods and technology must also be immediately developed and adapted to generation 4.0, let alone generation 5.0 have also been urged, the team explored the habits of generation 4.0 to 5.0, including the use of the internet and multimedia. So, students report the results of reading and discussion through presentations 
using video and utilizing the Phonetics Association links in several sources such as YouTube. Then, when practicing the field, students must also use multimedia to facilitate data retrieval and analysis.

After that, students' knowledge and activeness will be assessed in discussions in class. Then, the final grade of students will be compared with the final grade of students in previous phonology lectures.

\section{Result and Discussion}

Research on the development of educational quality was conducted on second semester students, the Indonesian Language and Literature Study Program, Faculty of Cultural Sciences, Andalas University, especially in phonology lectures. In accordance with the explanation in the previous section, the lecture system is carried out with student centered learning by utilizing multimedia, internet, and the practice of field lectures.

Phonology lectures are available in the even semester and are one of the chain subjects in the Indonesian Literature Study Program, in the field of linguistics. The series of courses starts from the Introduction to General Linguistics, Phonology, Morphology, Syntax, and semantics. The series is also a requirement to be able to follow the Linguistic Research Method Course and Linguistic Seminar. This course is considered a heavy subject for students because the material delivered is related to science, such as human anatomy, wave properties. The object of study is also quite difficult because the smallest part of the language is the sound of human language. Moreover, students have never received part of this lecture material during high school.

The mindset of the general public also affects students because the general public assumes that the Indonesian Literature Study Program will learn literary and language works such as language lessons in high school. So, many new students do not predict that they will get material like in this Phonology lecture. Therefore, innovative learning methods are needed and appropriate to the character of students. Based on this, several innovative methods were carried out in the SCL process. Class presentations are modified with video presentations showing group members sharing the results of their group discussions in turn in one video. Explanation by lecturers is also equipped with video shows related to the material. The practice of field lectures continues to be carried out as previously carried out.

So, the lecture schedule will continue as usual. The total number of meetings is 16 meetings with the number of credits is 3 . The eighth and sixteenth meetings are the midterm and final semester exams. Explanation of the lecture system and lecture contract delivered at the first meeting. At the first meeting, students were immediately grouped into small groups of 3-4 people. The number of members in each group is limited so that students work effectively.

Before meeting in class, students must look for material and discuss it in the small group. After that, the results of the discussion will be written in the form of reading reports. After that, the material is made in the form of ppt. Then, the selected group will present in class and discuss with other groups. The lecturer will review again at the last hour. After the Midterm Examination, students learn to transcribe language sounds. Before entering phoneme analysis material, students will conduct field lecture practices in order to practice the material that has been obtained and capture data for phonemic analysis. After that, students will make a research report. This activity is carried out in groups in areas agreed upon by students. 
The activity is carried out with modifications in the presentation section. Students are no longer asked to make power points, but are asked to submit the results of group discussions in the form of video. In the video, each group member must share the results of the discussion in turn. Then, the video is shown during the discussion in class. Participants in the discussion will still be given the opportunity to ask questions and make suggestions.

The selection of video media is considered more effective compared to ordinary ppt because, on video, each student must prepare for a presentation. Each student must appear in the video to explain the results of their discussion of the material provided. If the video duration is 12 minutes and the group members consist of 3 students, it means that each student must deliver the results of the presentation in 4 minutes. In addition, students as millennial generation known as Generation 4.0 will even be heading 5.0 close to the world of video and social media. Videos are more interactive and if they upload to social media, lecturers will add value. From the videos made by students, there are some student creations, some use the classroom setting and blackboard, and some also use the outdoors.

The video will be displayed in class according to the group's presentation schedule. To avoid cheating, students do not prepare themselves because they are not on their group presentation schedule, who will determine the presentation on the day and the same group can return to the presentation. It aims to make students always ready with all the material provided.

After that, the lecturer will also explain further and review what the students have to say. The explanation is complemented by videos on social media such as YouTube, as well as the latest scientific articles in reputable journals. Therefore, this research requires adequate internet access. Since most classrooms at Andalas University do not yet have complete facilities, the research team provides these facilities for students.

The final grade of students after attending lectures with this innovative method increased than before. Therefore, the university should immediately prepare each class with facilities that support innovative learning such as blended learning. In the research process, we experienced obstacles when it rained heavily because the class was not equipped with soundproofing. The sound of rain beat audio in the classroom. Therefore, class facilities should be equipped with equipment and facilities that are ready to face some disturbances such as rain and noise.

The results obtained from the application of the lecture system as described can be categorized as satisfying. Almost all students follow the lecture well which is indicated by the seriousness of most students in listening to what is delivered even though the material in this lecture is not purely social science. In addition, the final grade of students also increased from the previousyear that did not use the lecture system as in this semester.

The increase was calculated from students who received grades A to B. In the previous year (Even 2018/2019), students who received grades A to B were 64\%. Meanwhile, in this research semester, students who received grades A to B were $83 \%$. So, there was an increase in student grades from $64 \%$ to $83 \%$. Therefore, it is fitting for university leaders to pay attention to lecture facilities and infrastructure so that they can become innovative lectures in accordance with the times.

Several other studies also prove that the choice of instructional media and good collaboration between elements in the learning process largely determine the outcome of lectures. The results indicated that Multimedia-aided Teaching is more effective than the traditional one. Students' attitude towards science improves more if MAT method is used as compared to the traditional method of teaching [2]. 
In the teaching experiment results show that the application of multimedia technology in the teaching of physical education has greatly changed the students' physical source [3].

Other studies have found that teachers are recommended to use animation as an alternative to teach the competence of assembling and installing the brake system, because the results of the study show that animation media can improve learning outcomes [4]. In addition, there is also research that states that learning will be effective if several components, namely the teacher, students, objectives, material, media, methods, and evaluation interact and support each other [5].

\section{Conclusion}

To achieve maximum results from lectures, innovative teaching methods are needed in harmony with student development. The use of multimedia in the SCL process especially as a form of student discussion reports or as one of the media in explaining lecture material becomes one of the innovations that can improve the quality of lectures. However, the implementation of such lectures requires adequate support facilities. These facilities include; A strong internet network that supports access to video or data in large capacity; Soundproof lecture rooms; Desks for students must have enough space to place books, notes and portable computers; An audio amplifier that can be heard throughout the class. The position of the blackboard does not overlap with the infocus beam. Rightly, the university prepares all lecture halls with these facilities.

\section{References}

[1] A Wahyudin, Isa Sutikno. Keefektifan Pembelajaran Berbantuan Multimedia Menggunakan Metode Inkuiri Terbimbing untuk Meningkatkan Minat dan Pemahaman Siswa. 1, 2010, Jurnal Pendidikan Fisika Indonesia, Vol. 6 (2010)

[2] Iqbal Shah, Muhammad Khan Impact of Multimedia-ided Teaching of Students Academic Achievement and Attitude at Elementary Level.. 5, s.1. : US-China Education Review, 2015, Vol. 5. (2015)

[3] Yang Ju, Haibo Wan Analysis of Physical Education Mode BAsed on Computer Multimedia and Network System . 10, s.l. : International Journal of Database Theory And Application, 2016, Vol. 9. (2016)

[4] Beni Harsono, Soesanto, dan Samsudi. Perbedaan Hasil Belajar antara Metode Cera,ah Konvensional dengan Ceramah Berbantuan Media Animasi pasa Pem belajaran Kompetensi Perakitan dan Pemasangan Sistem Rem. 2, s.l. : Jurnal Pendidikan Teknik Mesin, 2009, Vol. 9. (2009)

[5] Pane, Aprida. Belajar dan Pembelajarab. 2, s.1. : Jurnal Fitrah Kajian Ilmu-ilmu Keisalaman, 2017, Vol. 3. (2017) 